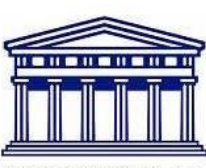

UNIVERSITY of the WESTERN CAPE

\title{
Geochemistry and weathering history of the Balfour sandstone formation, Karoo basin, South Africa: Insight to provenance and tectonic setting
}

Monica E. Oghenekome, Tapas K. Chatterjee, Jan M. van Bever Donker and Napoleon Q. Hammond

\begin{abstract}
:
Geochemical analysis on sandstones from clastic sediments was carried out to understand the tectonic setting and subsequent post-depositional change in the Karoo basinal fill of the fluvial deposits of the Balfour Formation during the Late Permian to Early Triassic period. The major and trace element analysis reveal a relatively homogeneous provenance for the sandstones. The geochemical analysis shows that these rocks are first order mature sediments, derived from igneous and/or meta-igneous rocks of a felsic composition. The results show that the sandstone consists of $\mathrm{SiO}_{2}$ (71.58 wt. \%), followed by $\mathrm{Al}_{2} \mathrm{O}_{3}$ (14.48 wt. \%), but with low contents of $\mathrm{Fe}_{2} \mathrm{O}_{3}+\mathrm{MgO}$ (4.09 wt. \%) and $\mathrm{TiO}_{2}$ (0.47 wt. \%). These sandstones are classified as litharenites and arkoses based on the elements constituent ratio of various schemed adopted. The sandstone in the provenance discrimination diagram plots in the dissected and transitional arc fields suggesting an active margin and continental island arc provenance, preserving the signature of a recycled provenance. The Chemical Index of Alteration (CIA) ranging from 63.56 to $67.10 \%$ suggests recycling processes, and that the source area has undergone a moderate degree of chemical weathering. The geochemical characteristics of the sediment suggest the source area of uplifted terrane of folded and faulted strata with detritus of sedimentary and metasedimentary origin.
\end{abstract}

The mineralogical compositions of sedimentary rocks do not reflect the mineralogy of the original source rocks due to post-depositional modification of the constituent grains. The geochemical composition of siliciclastic sedimentary rocks aids in the understanding of the setting and nature of source rocks. Many studies have shown that geochemical analysis of the siliciclastic rocks helps in the identification of their provenance and related depositional and post depositional processes (e.g., Banerjee and Banerjee, 2010; Jafarzadeh and Hosseini-Barzi, 2008; Liu et al., 2007; Rahmani and Suzuki, 2007; Cingolani et al., 2003; Raymond, 1995).

While the geochemical component/characteristics can be altered during weathering through oxidation (Taylor and McLennan, 1985), the bulk chemical composition is 
unaltered (McLennan et al., 1983). Geochemical analyses allow the clarification of the rocks composition not resolvable through petrographic analysis (Akarish and El-Gogary, 2008). Several studies have been carried out on various aspects of the Karoo basin sediments (e.g., Catuneanu and Elango (2001); Rubidge et al. (2000); Hiller and Stavrakis (1984); Haycock et al. (1997); Smith (1995); Visser and Dukas (1979); Kitching (1977); Tordiffe (1978); Keyser and Smith (1978)). None of those studies clarified the sources of the sediments using geochemical methods.

In this study, the geochemistry of selected representative sandstone samples from the Balfour Formation of the Karoo Supergroup was carried out using X-ray fluorescence spectrometry (XRF) analysis. This work contributes to the understanding of the depositional model of the Karoo Supergroup and the sedimentary environment along the southern margin of Gondwana.

\subsection{Generalized geology and stratigraphy}

The sediments studied are part of the southern Karoo Basin developed in response to the Late Palaeozoic to Early Mesozoic subduction episode of the palaeo-Pacific plate underneath the Gondwana plate (Catuneanu and Bowker, 2001; Catuneanu and Elango, 2001; Pysklywec and Mitrovica, 1999; Winter 1984; Lock, 1978). Fragments of the Gondwana foreland basin today are preserved across the world as the Parana Basin (South America), Karoo Basin (Southern Africa), Beacon Basin (Antarctica) and Bowen Basin (Australia) (Catuneanu, 2004; Catuneanu and Elango, 2001; Catuneanu et al., 1998).

\begin{tabular}{|c|c|c|c|c|c|c|}
\hline Period & Super-group & Group & Subgroup & $\begin{array}{l}\text { Formation } \\
\text { East of } 24^{\circ} \mathrm{E}\end{array}$ & Member & Environment of deposition \\
\hline \multirow[t]{2}{*}{ Jurassic } & $\mathrm{K}$ & Drakensberg & & & & Volcanic \\
\hline & A & & & Clarens & & Aeolian \\
\hline \multirow[t]{4}{*}{ Triassic } & $\mathrm{R}$ & & & Elliot & & Arid-fluvial \\
\hline & 0 & & & Molteno & & \\
\hline & 0 & B & TARKASTAD & Burgersdorp & & $\mathrm{F}$ \\
\hline & & $\mathrm{E}$ & & Katberg & & $\mathrm{L}$ \\
\hline $\mathrm{P}$ & & A & ADELAIDE & B & Palingkloof & $\mathrm{U}$ \\
\hline E & & $\mathrm{U}$ & & A & Elandsberg & $\mathrm{v}$ \\
\hline $\mathrm{R}$ & & $\mathrm{F}$ & & $\mathrm{L}$ & Barberskrans & I \\
\hline M & & 0 & & $\mathrm{~F}$ & Daggaboersnek & A \\
\hline I & & $\mathrm{R}$ & & 0 & Oudeberg & $\mathrm{L}$ \\
\hline A & & $\mathrm{T}$ & & $\mathrm{U}$ & & \\
\hline \multirow{8}{*}{$\mathrm{N}$} & & & & $\mathrm{R}$ & & \\
\hline & & & & Middleton & & Transitional (Deltaic) \\
\hline & & E & & Koonap & & \\
\hline & & $\mathrm{C}$ & & Waterford & & Deep-shallow marine \\
\hline & & C & & Fort Brown & & \\
\hline & & A & & Ripon & & \\
\hline & & & & Collingham & & \\
\hline & & & & Whitehill & & \\
\hline \multirow[t]{2}{*}{ Carboniferous } & & & & Prince Albert & & \\
\hline & & Dwyka & & & & Floating iceberg marine \\
\hline
\end{tabular}

The Karoo Basin responded to eight tectonic events related to the Panthalassan (PalaeoPacific) plate beneath Gondwana from the time of deposition of the Dwyka through to the Elliot Formation (Table 1) (Andersson and Worden, 2006; Bamford, 2004; Catuneanu et al., 2002; Smith et al., 1993; Catuneanu et al., 1998; SACS, 1980). These tectonic events 
produced variation in the depositional sedimentary successions within the Karoo setting (Catuneanu et al., 1998) and suggest changes in climate. The fourth tectonic orogenic paroxysm event is assigned to Balfour sedimentation (Catuneanu et al., 1998) from which the study is based. The clastic sediments from the Balfour Formation developed during the Late Permian (Tatarian) to Early Triassic (Scythian) period and representing the upper part of the Adelaide Subgroup (Table 1) of the Beaufort Group in the southeastern part of the Karoo Supergroup along the southern margin of Gondwana continent in South Africa (Oghenekome et al., 2016; Catuneanu et al., 1998, 2002, 2005; Catuneanu and Bowker, 2001; Catuneanu and Elango, 2001 Rubidge, 2005; Pysklywec and Mitrovica, 1999; Johnson et al., 1996; Smith et al., 1993; Johnson, 1991; Tankard et al., 1982). The Balfour Formation comprises two finning upward megacycles of sedimentary deposits with a change in the sediment supply pattern from low-sinuosity to high-sinuosity river systems, which reflect both braided and meandering river deposits. Lithostratigraphically, it is subdivided into five members viz, the Oudeberg, Daggaboersnek, Barberskrans, Elandsberg, and Palingkloof Members (Table 1) (Oghenekome et al., 2016; Johnson et al., 2006; DeKock and Kirschvink, 2003; Tordiffe et al., 1985; SACS, 1980). Sandstones from each Member were studied to understand the provenance of the Balfour Formation.

\section{Methodology and results}

The geochemical analysis was on selected representative samples from exposures in the vicinity of the towns of Adelaide and Bedford (Fig. 1). The trace element analysis was from pressed pellets whereas major elements analyses were from fused glass disks. The rock samples were reduced to chips of $>10 \mathrm{~mm}$ and pulverized in a tungsten carbide crusher for the major and trace elements. These pulverized samples were analyzed at the Council for Geoscience in Pretoria, South Africa.

\subsection{Major elements}

The bulk geochemical data from the XRF analyses of major and minor element concentrations are shown in Tables 2 and 3. The sandstones are rich in $\mathrm{SiO}_{2}$ followed by $\mathrm{Al}_{2} \mathrm{O}_{3}$ in order of abundance. $\mathrm{SiO}_{2}$ ranges from 68.41 to $76.20 \mathrm{wt}$ \% and has an overall average $\mathrm{SiO}_{2}$ concentration of $71.58 \mathrm{wt}$. \% in the analyzed samples. The Oudeberg Member, which is the youngest member of the Formation, has a $\mathrm{SiO}_{2}$ concentration of 69.38 wt. \% in the lower parts and $73.67 \mathrm{wt}$. \% in the upper succession of the measured section. $\mathrm{Al}_{2} \mathrm{O}_{3}$ composition ranges between 13.17 and 15.44 wt. \%. The sandstone also contains low percentages of $\mathrm{TiO}_{2}, \mathrm{MnO}$ and $\mathrm{MgO}$. There is no significant variation of phosphorus oxide $\left(\mathrm{P}_{2} \mathrm{O}_{5}\right)$ across the samples. The sandstones are depleted in $\mathrm{CaO}$ which ranges from 0.87 to 2.27 wt. \%.

\subsection{Trace elements}

It is accepted that trace elements composition reflects the signature of the parent materials (Bhatia and Crook, 1986; Raymond, 1995) and makes them relevant for provenance and depositional setting studies. The trace elements are not affected by diagenesis and metamorphism (McLennan et al., 2001). The trace elements such as La, Y, Sc, Sr, Cr, Th, Zr, 
$\mathrm{Hf}, \mathrm{Nb}$ and $\mathrm{TiO}_{2}$ among other major elements are best suited for provenance and tectonic setting, analyses due to their low mobility during sedimentation processes (McLennan et al.,1983; Holland, 1978). The Sr content is very high in the sandstone of the Balfour Formation, ranging from 226 to $421 \mathrm{ppm}$, (Table 3). The Th/U ratio is important as it defines the state of weathering under oxidizing conditions. This $\mathrm{Th} / \mathrm{U}$ ratio increases upwards in the Formation succession. The ratio of $\mathrm{Zr} / \mathrm{Sc}$ increases from 0.95 to $1.90 \mathrm{ppm}$ with an accompanying decrease in the Th/Sc ratio. A discrimination plot of $\mathrm{Zr} / \mathrm{Sc}$ against $\mathrm{Th} / \mathrm{Sc}$ after McLennan et al. (1983) (Fig. 2) is used to determine the composition of the source rocks and provides insight into the degree of fractionation of the intrusive precursors. The relative abundance of zircon in the sandstone is also reflected by the high $\mathrm{Zr} / \mathrm{Sc}$ ratio, which ranges from 19.69 to $29.22 \mathrm{ppm}$. A plot of $\mathrm{SiO}_{2}$ versus $\mathrm{Zr} / \mathrm{Sc}$ (Fig. 3) suggests significant reworking and selective sorting during transportation.

\subsection{Classification of the sandstone}

The geochemical classification of the Balfour Formation sandstone is based on the Logarithmic plots of $\mathrm{Fe}_{2} \mathrm{O}_{3} / \mathrm{K}_{2} \mathrm{O}$ versus $\mathrm{Al}_{2} \mathrm{O}_{3} / \mathrm{SiO}_{2}$ after Herron (1988) (Fig. 5). The Herron sand classification system (Herron, 1988) shows the relationship between element composition, mineralogy and rock type. A variant plot of $\mathrm{SiO}_{2}$ against total $\left(\mathrm{Al}_{2} \mathrm{O}_{3}+\mathrm{K}_{2} \mathrm{O}_{3}+\mathrm{Na} 2 \mathrm{O}\right)$ (Fig. 6) proposed by Suttner and Dutta (1986) is used to study the maturity of the sandstones as seen in Fig. 6. 


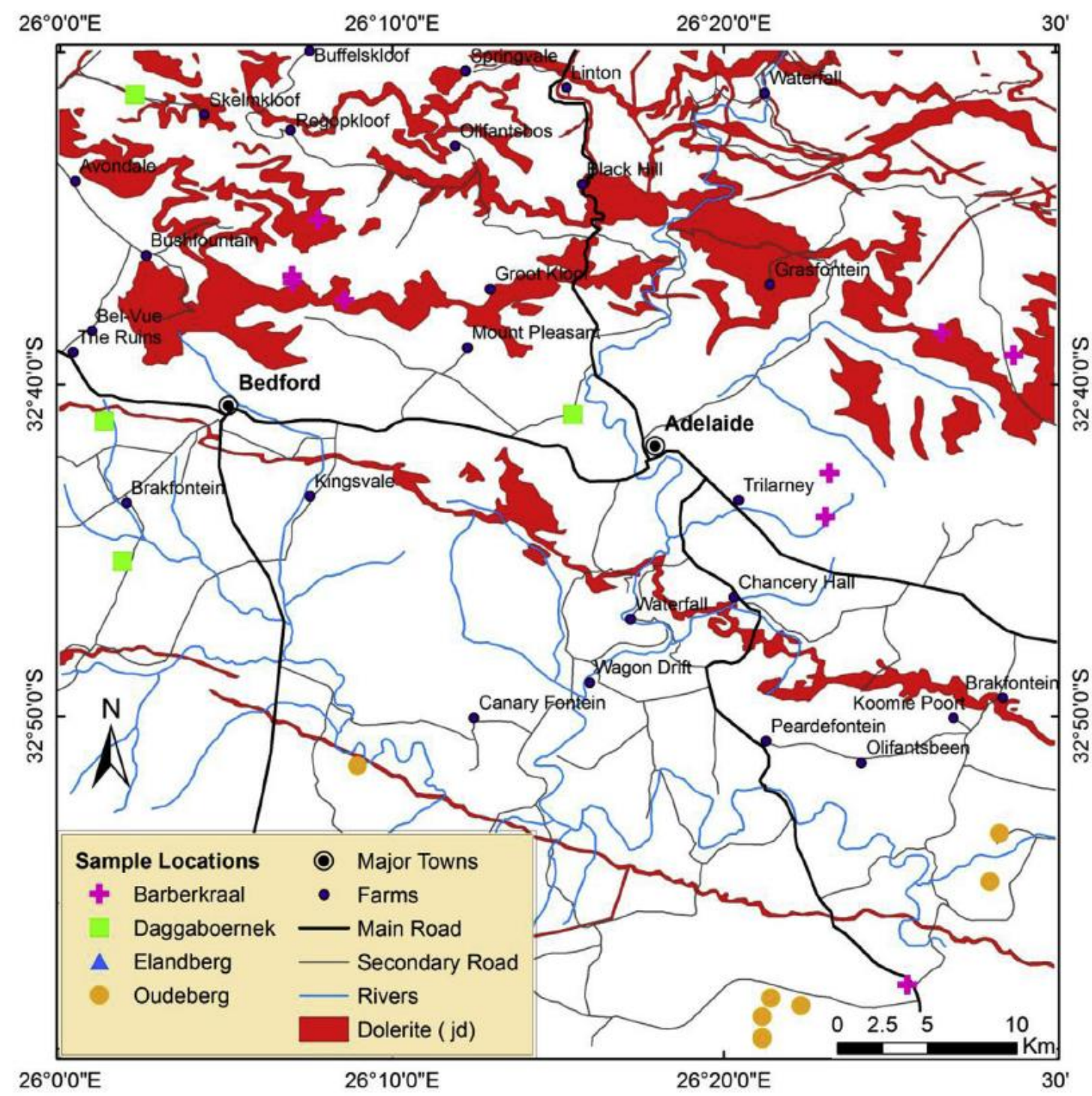

Fig. 1. Sample locations in the vicinity of the towns of Bedford and Adelaide on the various members of the Balfour Formation, Eastern Cape Province.

\subsection{Provenance and tectonic setting}

Certain mobile elements such as $\mathrm{Fe}, \mathrm{Ca}, \mathrm{Na}, \mathrm{K}$ and $\mathrm{Mg}$, and immobile trace elements such as Th, Sc, Zr, Hf, V, Cr and Co are useful for provenance and tectonic setting determination (George and Christian, 2001; Asiedu et al., 2000; Bhatia, 1983, Bhatia and Crook, 1986; Taylor and McLennan, 1985). This is due to their low mobility during sedimentary processes, and low residence time in seawater as suggested by Cingolani et al. (2003). The geochemical composition of some of these elements (silicon oxide, aluminium oxide, iron oxide, magnesium oxide, chromium, nickel, titanium, scandium and Vanadium) in the studied samples was plotted on discrimination diagrams to determine tectonic setting per Bhatia (1983). In addition, plots of $\mathrm{TiO}_{2}$ versus $\mathrm{Fe}_{2} \mathrm{O}_{3}+\mathrm{MgO}$ and $\mathrm{Al}_{2} \mathrm{O}_{3} / \mathrm{SiO}_{2}$ versus $\mathrm{Fe}_{2} \mathrm{O}_{3}+\mathrm{MgO}$ (Fig. $4 \mathrm{a}$ and $\mathrm{b}$ ) were also used for the investigation, pointing toward active continental margin and continental island arc setting. Immobile trace elements in the sandstones show enrichment in $\mathrm{Cr}$ ranging between 36 and $58 \mathrm{ppm}$. The relative 
abundances of $\mathrm{V}, \mathrm{Cr}, \mathrm{Ni}, \mathrm{Ti}$, and $\mathrm{Sc}$ suggest mafic input into the sedimentary detritus (Bhatia and Crook, 1986; Taylor and McLennan, 1985; Bhatia, 1983).

\subsection{Weathering conditions in the source area}

Chemical weathering affects the composition of siliciclastic sediments, and changes the principal constituent of the sedimentary rock (Fedo et al., 1995). The weathering effects on the source rocks are evaluated using the Chemical Index of Alteration (CIA) as applied to non-calcareous rocks (Yang and Du, 2017; Scheffler et al., 2003; Fedo et al., 1995). The CIA value reflects the degree of chemical weathering of the detritus incorporated into the source rock (Cingolani et al., 2003) and therefore provides an estimate of the climatic conditions during the formation of the sedimentary rocks. The CIA index of the sandstones was calculated as $\mathrm{CIA}=\left[\mathrm{Al}_{2} \mathrm{O}_{3} /\left(\mathrm{Al}_{2} \mathrm{O}_{3}+\mathrm{CaO}+\mathrm{Na} 2 \mathrm{O}+\mathrm{K}_{2} \mathrm{O}\right)\right]$ x100; and its value ranges from $64 \%$ to $67 \%$ (Table 2) with an overall average of $66.15 \%$ for the sandstones. The high values of the CIA reflect increasing proportions of clay minerals with respect to feldspar, which can lead to an increased proportion of $\mathrm{Al}_{2} \mathrm{O}_{3}$ kaolinite) as seen in this study.

\begin{tabular}{|c|c|c|c|c|c|c|c|c|c|c|c|c|c|}
\hline Samples & ODST: 1 & ODST: 2 & ODST: 3 & DGST: 1 & DGST: 2 & DGST: 3 & BBST: 1 & BBST: 2 & BBST: 3 & ELST: 1 & ELST: 2 & ELST: 3 & Average \\
\hline $\mathrm{SiO}_{2}$ & 73.50 & 69.38 & 68.38 & 73.31 & 73.33 & 70.80 & 68.41 & 70.67 & 70.47 & 70.31 & 76.20 & 74.47 & 71.60 \\
\hline $\mathrm{TiO}_{2}$ & 0.45 & 0.53 & 0.54 & 0.32 & 0.43 & 0.49 & 0.57 & 0.39 & 0.38 & 0.59 & 0.30 & 0.31 & 0.44 \\
\hline $\mathrm{Al}_{2} \mathrm{O}_{3}$ & 13.17 & 14.88 & 14.85 & 14.16 & 14.49 & 15.44 & 15.33 & 14.84 & 14.85 & 14.98 & 13.29 & 12.99 & 14.44 \\
\hline $\mathrm{Fe}_{2} \mathrm{O}_{3}(\mathrm{t})$ & 2.77 & 3.73 & 3.74 & 2.54 & 2.75 & 295 & 4.54 & 3.43 & 3.40 & 3.96 & 1.89 & 1.98 & 3.14 \\
\hline $\mathrm{MnO}$ & 0.06 & 0.06 & 0.06 & 0.06 & 0.04 & 0.04 & 0.06 & 0.08 & 0.08 & 0.08 & 0.03 & 0.04 & 0.06 \\
\hline $\mathrm{MgO}$ & 0.71 & 1.01 & 1.04 & 0.75 & 0.60 & 0.88 & 1.40 & 1.23 & 1.24 & 1.25 & 0.42 & 0.55 & 0.92 \\
\hline $\mathrm{CaO}$ & 1.74 & 2.26 & 2.30 & 2.32 & 0.87 & 1.15 & 2.17 & 1.37 & 1.35 & 1.56 & 1.32 & 2.31 & 1.73 \\
\hline $\mathrm{Na}_{2} \mathrm{O}$ & 3.16 & 3.63 & 3.32 & 3.85 & 5.65 & 4.88 & 2.31 & 4.88 & 4.85 & 3.34 & 3.01 & 3.09 & 3.83 \\
\hline $\mathrm{K}_{2} \mathrm{O}$ & 2.27 & 2.50 & 2.52 & 1.38 & 1.03 & 1.71 & 2.97 & 1.40 & 1.45 & 2.72 & 2.46 & 254 & 2.08 \\
\hline $\mathrm{P}_{2} \mathrm{O}_{5}$ & 0.10 & 0.11 & 0.10 & 0.86 & 0.10 & 0.11 & 0.18 & 0.09 & 0.10 & 0.16 & 0.08 & 0.08 & 0.17 \\
\hline $\mathrm{Cr}_{2} \mathrm{O}_{3}$ & 0.00 & 0.00 & 0.00 & $<0.001$ & $<0.001$ & 0.00 & 0.00 & 0.00 & 0.00 & 0.00 & $<0.001$ & $<0.001$ & 0.00 \\
\hline L.O.I. & 2.28 & 2.20 & 2.24 & 1.25 & 1.19 & 1.75 & 1.94 & 1.58 & 1.95 & 1.49 & 1.88 & 2.29 & 1.84 \\
\hline Total & 100.22 & 100.30 & 100.30 & 100.79 & 100.48 & 100.19 & 99.89 & 99.98 & 100.12 & 100.44 & 100.89 & 100.64 & 100.35 \\
\hline $\mathrm{H}_{2} \mathrm{O}$ & 1.19 & 0.71 & 0.71 & 0.45 & 0.60 & 0.89 & 0.94 & 0.52 & 0.56 & 0.62 & 1.65 & 0.86 & 0.81 \\
\hline $\mathrm{SiO}_{2} / \mathrm{Al}_{2} \mathrm{O}_{3}$ & 5.58 & 4.66 & 4.60 & 5.18 & 5.06 & 4.58 & 4.46 & 4.76 & 4.75 & 4.69 & 5.73 & 5.73 & 4.98 \\
\hline $\mathrm{AlO}_{2} \mathrm{O}_{3} / \mathrm{TiO}_{2}$ & 25.31 & 44.12 & 42.11 & 26.77 & 38.05 & 39.08 & 44.72 & 33.91 & 31.79 & 29.42 & 27.86 & 27.30 & 34.20 \\
\hline $\mathrm{Na}_{2} \mathrm{O} / \mathrm{K}_{2} \mathrm{O}$ & 1.39 & 1.45 & 1.32 & 2.80 & 5.48 & 285 & 0.78 & 3.49 & 3.34 & 1.23 & 1.23 & 1.21 & 2.21 \\
\hline $\mathrm{Al}_{2} \mathrm{O}_{3} / \mathrm{SiO}_{2}$ & 0.18 & 0.21 & 0.22 & 0.19 & 0.20 & 0.22 & 0.22 & 0.21 & 0.21 & 0.21 & 0.17 & 0.17 & 0.20 \\
\hline $\mathrm{K}_{2} \mathrm{O} / \mathrm{Na}_{2} \mathrm{O}$ & 0.72 & 0.69 & 0.76 & 0.36 & 0.18 & 0.35 & 1.29 & 0.29 & 0.30 & 0.82 & 0.82 & 0.82 & 0.62 \\
\hline $\mathrm{Na}_{2} \mathrm{O}+\mathrm{CaO}$ & 4.91 & 5.89 & 5.62 & 6.17 & 6.52 & 6.03 & 4.48 & 6.26 & 6.20 & 4.89 & 4.33 & 5.39 & 5.56 \\
\hline $\mathrm{Fe}_{2} \mathrm{O}_{3}+\mathrm{MgO}$ & 3.48 & 4.74 & 4.78 & 3.29 & 3.35 & 3.83 & 5.94 & 4.66 & 4.64 & 5.21 & 2.31 & 252 & 4.06 \\
\hline $\mathrm{Al}_{2} \mathrm{O}_{3}+\mathrm{Na}_{2} \mathrm{O}+\mathrm{K}_{2} \mathrm{O}$ & 18.60 & 21.01 & 20.70 & 19.39 & 21.17 & 22.03 & 20.61 & 21.12 & 21.15 & 21.04 & 18.76 & 18.62 & 20.35 \\
\hline $\mathrm{Fe}_{2} \mathrm{O}_{3} / \mathrm{K}_{2} \mathrm{O}$ & 1.22 & 1.49 & 1.48 & 1.85 & 2.67 & 1.72 & 1.53 & 2.45 & 2.34 & 1.46 & 0.77 & 0.78 & 1.65 \\
\hline CIA & 64.72 & 63.94 & 64.57 & 65.24 & 65.75 & 66.63 & 67.29 & 65.97 & 66.00 & 66.31 & 66.18 & 62.07 & 65.39 \\
\hline
\end{tabular}

Barberskrans sandstone, ELST: Elandsberg sandstone. 
Table 3

Trace element data of sandstone members from the Balfour Formation, Eastern Cape Province, South Africa; all concentrations are in parts per million (ppm).

\begin{tabular}{|c|c|c|c|c|c|c|c|c|c|c|c|c|c|}
\hline Samples & ODST: 1 & ODST: 2 & ODST:3 & DGST:1 & DGST:2 & DGST:3 & BBST:1 & BBST:2 & BBST:3 & ELST:1 & ELST:2 & ELST:3 & Average \\
\hline As & 8.2 & 5.5 & 6.1 & 6.2 & 6.5 & 6.4 & $<4$ & $<4$ & $<4$ & $<4$ & $<4$ & $<4$ & 6.5 \\
\hline $\mathrm{Ba}$ & 446 & 626 & 623 & 595 & 555 & 565 & 610 & 403 & 407 & 643 & 562 & 732 & 563.9 \\
\hline $\mathrm{Bi}$ & $<3$ & $<3$ & $<3$ & $<3$ & $<3$ & $<3$ & $<3$ & $<3$ & $<3$ & $<3$ & $<3$ & $<3$ & 0.0 \\
\hline $\mathrm{Ce}$ & 75 & 55 & 56 & 49 & 54 & 56 & 61 & 53 & 56 & 69 & 41 & 42 & 55.6 \\
\hline Co & 11 & 10 & 10 & 6.8 & 8.2 & 8.2 & 11 & 14 & 12 & 12 & 4.8 & 6 & 9.5 \\
\hline $\mathrm{Cr}$ & 48 & 56 & 50 & 45 & 36 & 42 & 43 & 48 & 46 & 58 & 41 & 39 & 46.0 \\
\hline Cs & $<5$ & $<5$ & $<5$ & $<5$ & $<5$ & $<5$ & $<5$ & $<5$ & $<5$ & $<5$ & $<5$ & $<5$ & 0.0 \\
\hline $\mathrm{Cu}$ & 8.7 & 8.5 & 8.6 & 3.1 & 11 & 11 & 12 & 17 & 16 & 9.8 & 12 & 4.6 & 10.2 \\
\hline Ga & 15 & 18 & 16 & 15 & 16 & 15 & 18 & 17 & 17 & 17 & 12 & 14 & 15.8 \\
\hline $\mathrm{Ge}$ & 1.1 & 1.6 & 1.5 & 2.4 & 1.3 & 1.3 & $<1$ & 1.3 & 1.4 & 1 & $<1$ & 1.4 & 1.4 \\
\hline $\mathrm{Hf}$ & $<3$ & 3.7 & $<3$ & 8.1 & 3.3 & 3.5 & 7.2 & 3.7 & 3.5 & 5.9 & $<3$ & 4.5 & 4.8 \\
\hline $\mathrm{La}$ & 47 & 34 & 32 & 35 & 39 & 35 & 43 & 33 & 43 & 42 & 27 & 27 & 36.4 \\
\hline Mo & $<2$ & $<2$ & $<2$ & $<2$ & $<2$ & $<2$ & $<2$ & $<2$ & $<2$ & $<2$ & $<2$ & $<2$ & 0.0 \\
\hline $\mathrm{Nb}$ & 8.7 & 9.8 & 8.6 & 8.8 & 10 & 8.7 & 13 & 9.3 & 12 & 12 & 6.7 & 8.6 & 9.7 \\
\hline $\mathrm{Nd}$ & 33 & 28 & 32 & 26 & 29 & 28 & 33 & 26 & 28 & 34 & 22 & 22 & 28.4 \\
\hline $\mathrm{Ni}$ & 12 & 12 & 9.5 & 9.9 & 9.7 & 9.7 & 15 & 15 & 15 & 15 & 6.9 & 8.5 & 11.5 \\
\hline $\mathrm{Pb}$ & 16 & 18 & 18 & 16 & 18 & 19 & 21 & 17 & 20 & 19 & 14 & 15 & 17.6 \\
\hline $\mathrm{Rb}$ & 74 & 81 & 85 & 43 & 65 & 68 & 127 & 59 & 57 & 107 & 79 & 97 & 78.5 \\
\hline $\mathrm{Sc}$ & 8.2 & 9.5 & 9.6 & 7 & 7.4 & 7.5 & 9.1 & 8.7 & 8.5 & 7.8 & 5.5 & 5.1 & 7.8 \\
\hline $\mathrm{Se}$ & $<1$ & $<1$ & $<1$ & $<1$ & $<1$ & $<1$ & $<1$ & $<1$ & $<1$ & $<1$ & $<1$ & $<1$ & 0.0 \\
\hline $\mathrm{Sm}$ & $<10$ & $<10$ & $<10$ & $<10$ & $<10$ & $<10$ & $<10$ & $<10$ & $<10$ & $<10$ & $<10$ & $<10$ & 0.0 \\
\hline $\mathrm{Sr}$ & 226 & 421 & 263 & 249 & 308 & 265 & 332 & 281 & 286 & 262 & 288 & 284 & 288.8 \\
\hline $\mathrm{Ta}$ & $<2$ & $<2$ & $<2$ & $<2$ & $<2$ & $<2$ & $<2$ & $<2$ & $<2$ & $<2$ & $<2$ & $<2$ & 0.0 \\
\hline Th & 11 & 9.4 & 9.1 & 9.2 & 11 & 11 & 13 & 11 & 13 & 14 & 7.8 & 9.7 & 10.8 \\
\hline $\mathrm{Tl}$ & $<3$ & $<3$ & $<3$ & $<3$ & $<3$ & $<3$ & $<3$ & $<3$ & $<3$ & $<3$ & $<3$ & $<3$ & 0.0 \\
\hline $\mathrm{U}$ & $<2$ & $<2$ & $<2$ & $<2$ & $<2$ & $<2$ & $<2$ & $<2$ & $<2$ & $<2$ & $<2$ & $<2$ & 0.0 \\
\hline V & 68 & 75 & 65 & 61 & 60 & 60 & 67 & 71 & 65 & 73 & 39 & 42 & 62.2 \\
\hline W & $<3$ & $<3$ & $<3$ & 4.9 & $<3$ & $<3$ & $<3$ & $<3$ & $<3$ & $<3$ & $<3$ & $<3$ & 4.9 \\
\hline $\mathrm{Y}$ & 16 & 19 & 18 & 17 & 20 & 25 & 28 & 19 & 26 & 25 & 16 & 17 & 20.5 \\
\hline $\mathrm{Yb}$ & $<3$ & $<3$ & $<3$ & $<3$ & $<3$ & $<3$ & $<3$ & $<3$ & $<3$ & 3.2 & $<3$ & $<3$ & 3.2 \\
\hline $\mathrm{Zn}$ & 45 & 55 & 46 & 41 & 50 & 50 & 70 & 60 & 70 & 60 & 34 & 36 & 51.4 \\
\hline $\mathrm{Zr}$ & 169 & 216 & 189 & 188 & 210 & 215 & 220 & 136 & 230 & 217 & 146 & 149 & 190.4 \\
\hline $\mathrm{Cr} / \mathrm{Ni}$ & 4.00 & 4.67 & 5.26 & 4.55 & 3.71 & 4.33 & 2.87 & 3.20 & 3.07 & 3.87 & 5.94 & 4.59 & 4.2 \\
\hline Th/u & 1.34 & 0.99 & 0.95 & 1.31 & 1.49 & 1.47 & 1.43 & 1.26 & 1.53 & 1.79 & 1.42 & 1.90 & 1.4 \\
\hline $\mathrm{Zr} / \mathrm{Th}$ & 15.36 & 22.98 & 20.77 & 20.43 & 19.09 & 19.55 & 16.92 & 12.36 & 17.69 & 15.50 & 18.72 & 15.36 & 17.9 \\
\hline $\mathrm{Th} / \mathrm{Sc}$ & 1.34 & 0.99 & 0.95 & 1.31 & 1.49 & 1.47 & 1.43 & 1.26 & 1.53 & 1.79 & 1.42 & 1.90 & 1.4 \\
\hline $\mathrm{Zr} / \mathrm{Sc}$ & 20.61 & 22.74 & 19.69 & 26.86 & 28.38 & 28.67 & 24.18 & 15.63 & 27.06 & 27.82 & 26.55 & 29.22 & 24.8 \\
\hline
\end{tabular}

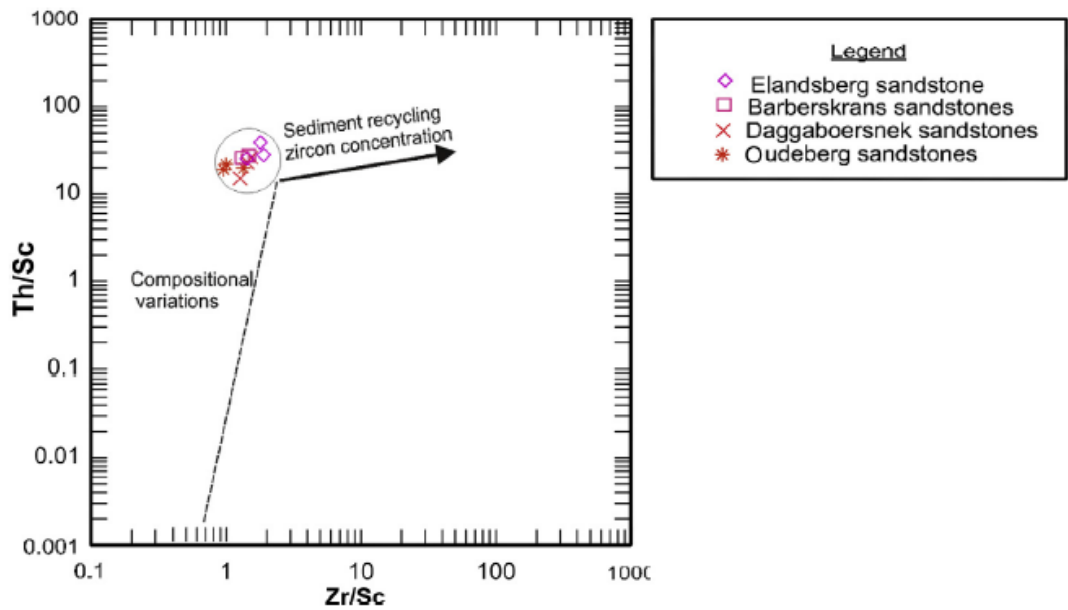

Fig. 2. Discrimination plot of $\mathrm{Zr} / \mathrm{Sc}$ against $\mathrm{Th} / \mathrm{Sc}$ ratios (after McLennan et al., 1983). Plot shows concentration of zircon with high $\mathrm{Zr} / \mathrm{Sc}$ ratio in the trailing edge (arrow) indicating the dominant heavy mineral in the sandstone, which is attributable to sedimentary sorting and recycling. 

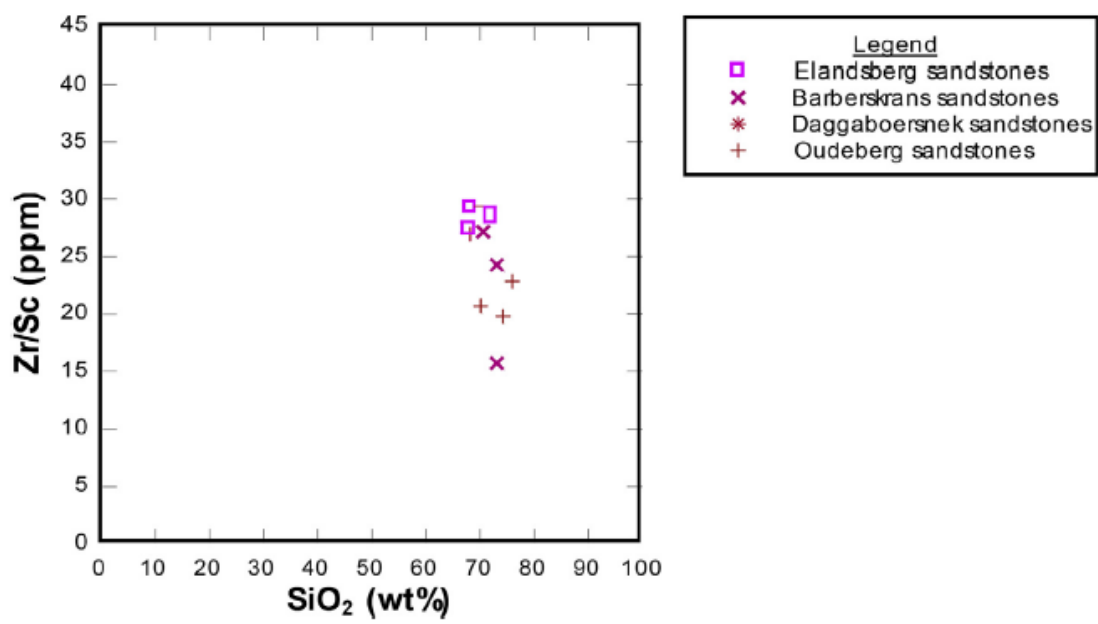

Fig. 3. Scatter plot of $\mathrm{SiO}_{2}$ versus $\mathrm{Zr} / \mathrm{Sc}$ showing zircon concentration increasing upward in the section in the Balfour Formation using the method proposed by Cingolani et al. (2003).
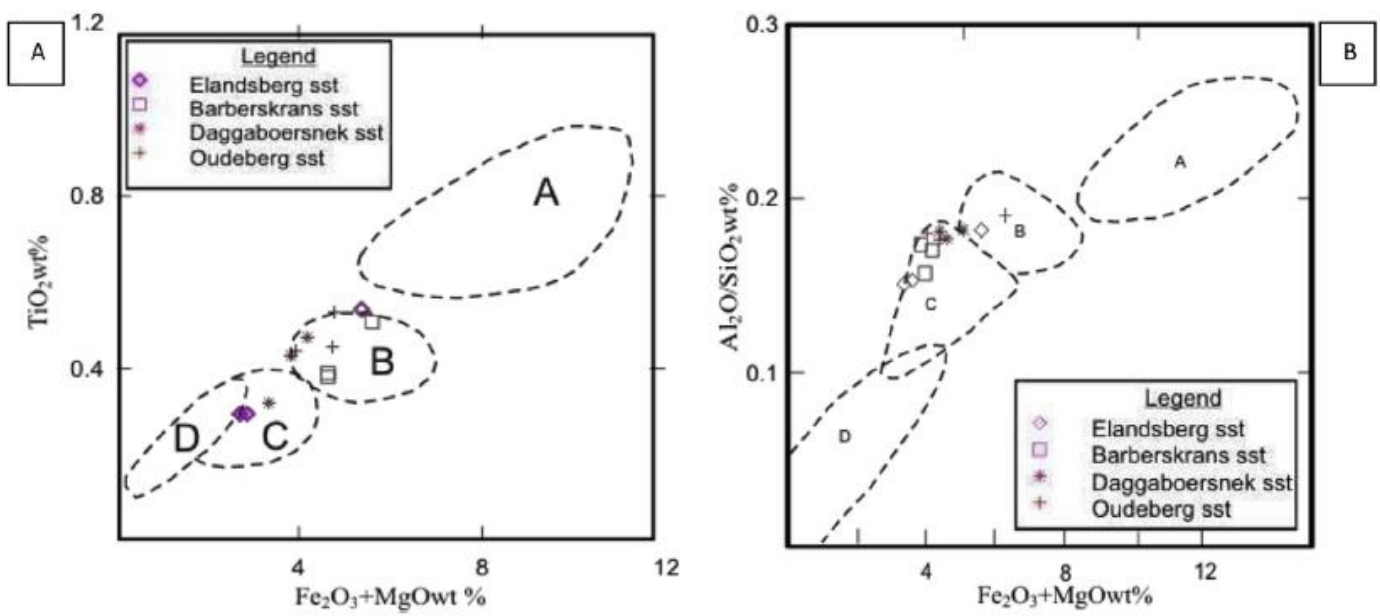

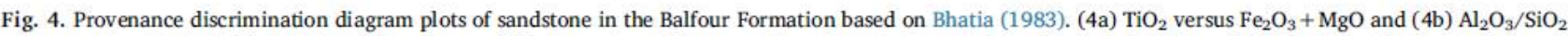
versus $\mathrm{Fe} 2 \mathrm{O}_{3}+\mathrm{MgO}$; Fields A, B, C and D represent fields for various plate tectonic regimes. A (Oceanic Island Arc); B (Continental Island Arc); C (Active Continental Margin); D (Passive Margin). The abbreviation in the legend "sst" represents sandstone.

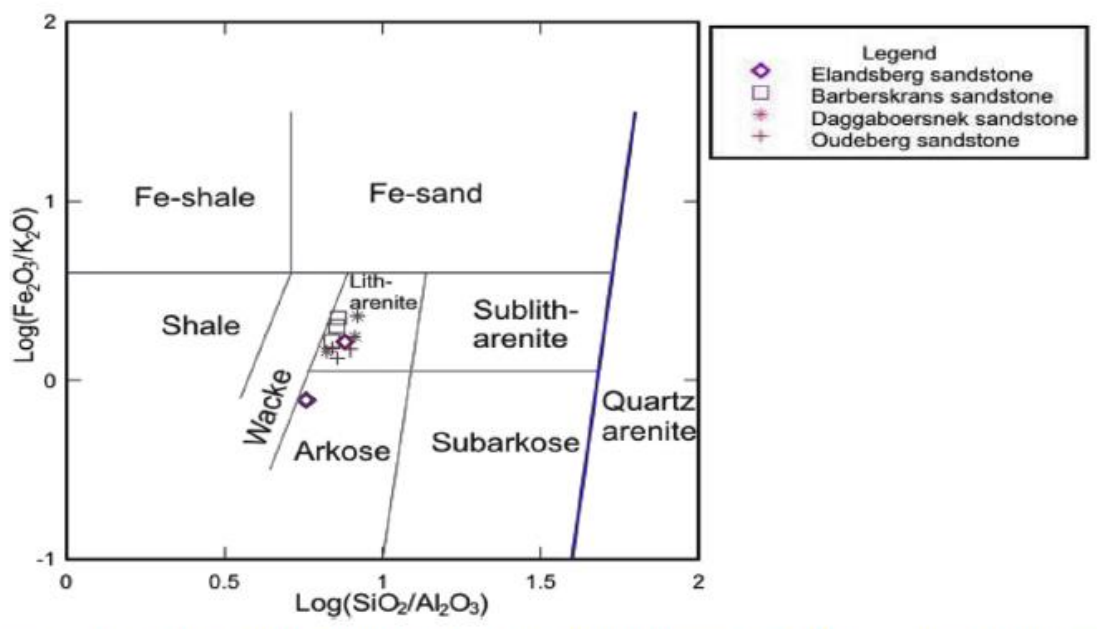

Fig. 5. Geochemical classification of the Balfour sandstones using the Herron classification (Herron, 1988). The sandstones plot in the litharenite and arkose fields. 


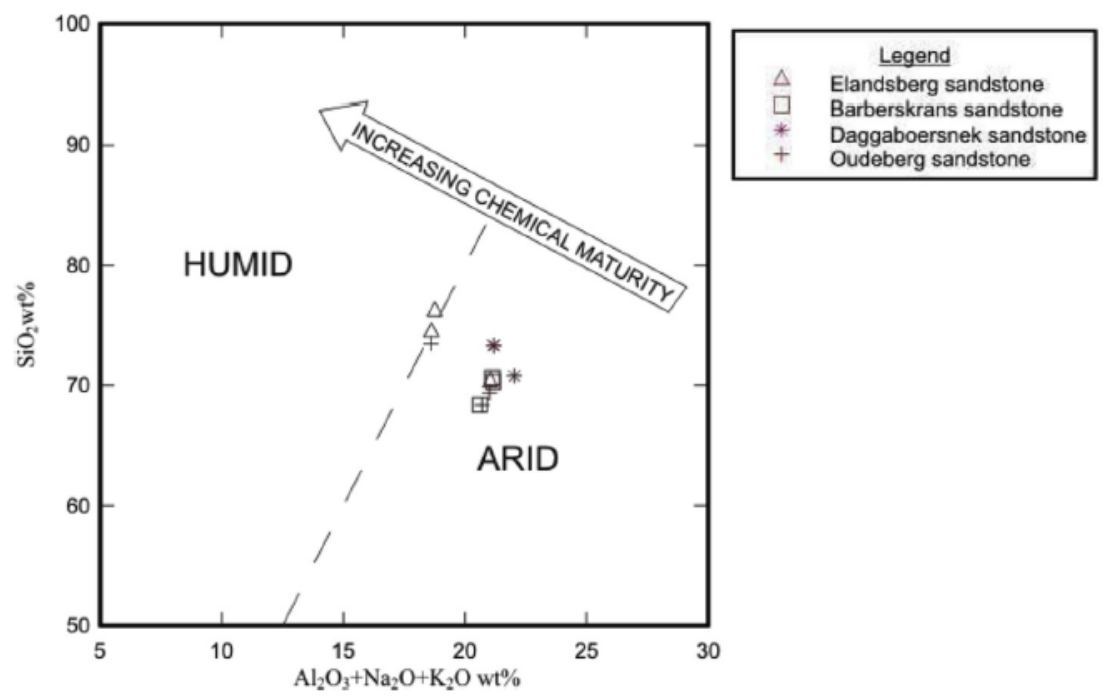

Fig. 6. Bi-variant plot of $\mathrm{Al}_{2} \mathrm{O}_{3}+\mathrm{K}_{2} \mathrm{O}+\mathrm{Na}_{2} \mathrm{O}$ versus $\mathrm{SiO}_{2}$ showing the chemical maturity trend of the Balfour sandstone on the diagram as proposed by Suttner and Dutta (1986).

According to Fedo et al. (1995) the closer the CIA value is to 100, the more weathered the source rock. The results show that the samples experienced moderate to high degrees of weathering, either from the original source or during transport but before deposition. The CIA value when plotted in an A-CN-K diagram (Figs. 7 and 8), is used to deduce the chemical weathering trend (Nyakairu and Koeberl, 2001). The initial stage of weathering is inferred form bulk source composition and the extent of post-depositional K-metasomatism, if present (Akarish and El-Gohary (2008); McLennan et al. (1983)). The samples plot in the lower part of the igneous composition field which indicates a lower degree of alteration. The CIA value of $65.39 \%$ and corresponding $\mathrm{SiO}_{2}$ compositional value that ranges from $68.41 \%$ to $76.20 \%$ (Figs. 8 and 9) suggest weathered an ancient granitic source.

\section{Discussion}

The overall average of $\mathrm{SiO}_{2}(71.58 \%)$ implies that all the sandstones are rich in silicate minerals derived from either a silica-rich provenance or weathered granite-gneiss or preexisting sedimentary terrane (Rahmani and Suzuki, 2007). The $\mathrm{K}_{2} \mathrm{O} / \mathrm{Na}_{2} \mathrm{O}$ ratio is a chemical provenance indicator. The scheme proposed by Crook (1974) was followed, this scheme subdivides sandstones into quartz-poor, quartz-intermediate and quartz-rich based on their $\mathrm{SiO}_{2}$ contents (Fig. 10). When used in conjunction with the $\mathrm{K}_{2} \mathrm{O} / \mathrm{Na}_{2} \mathrm{O}$ ratio, as each ratio is assigned to a specific plate tectonic environment, in our case all of the sandstone samples plot in the quartz-intermediate class $\left(\mathrm{SiO}_{2}\right.$ content of $71.58 \%$ and $\mathrm{K}_{2} \mathrm{O} / \mathrm{Na}_{2} \mathrm{O}>1$; Table 2). The ratio of incompatible versus compatible elements is useful for differentiating between felsic and mafic source components (George and Christian, 2001). Thus, a low value of the $\mathrm{TiO}_{2}$ and a high value of $\mathrm{Al}_{2} \mathrm{O}_{3}$ suggest an igneous origin. The $\mathrm{Al}_{2} \mathrm{O}_{3} / \mathrm{TiO}_{2}$ ratio increases from 3 to 8 for mafic igneous rocks, from 8 to 12 for intermediate igneous rocks and from 21 to 70 for felsic igneous rocks (Hayashi et al., 1997). The $\mathrm{Al}_{2} \mathrm{O}_{3} / \mathrm{TiO}_{2}$ ratio of 32.1 suggest a felsic igneous origin for sedimentary rocks of the Balfour 
Formation. The abundance of chromium (Cr) and nickel (Ni) in siliciclastic sediments are considered a useful indicator in provenance studies (Nagarajan et al., 2007). Wrafter and Graham (1989) indicated that high contents of $\mathrm{Cr}$ and $\mathrm{Ni}$ are mainly associated with sediments derived from ultramafic rocks while Armstrong-Altrin et al. (2004) indicated that a low concentration of $\mathrm{Cr}$ indicates a felsic provenance.

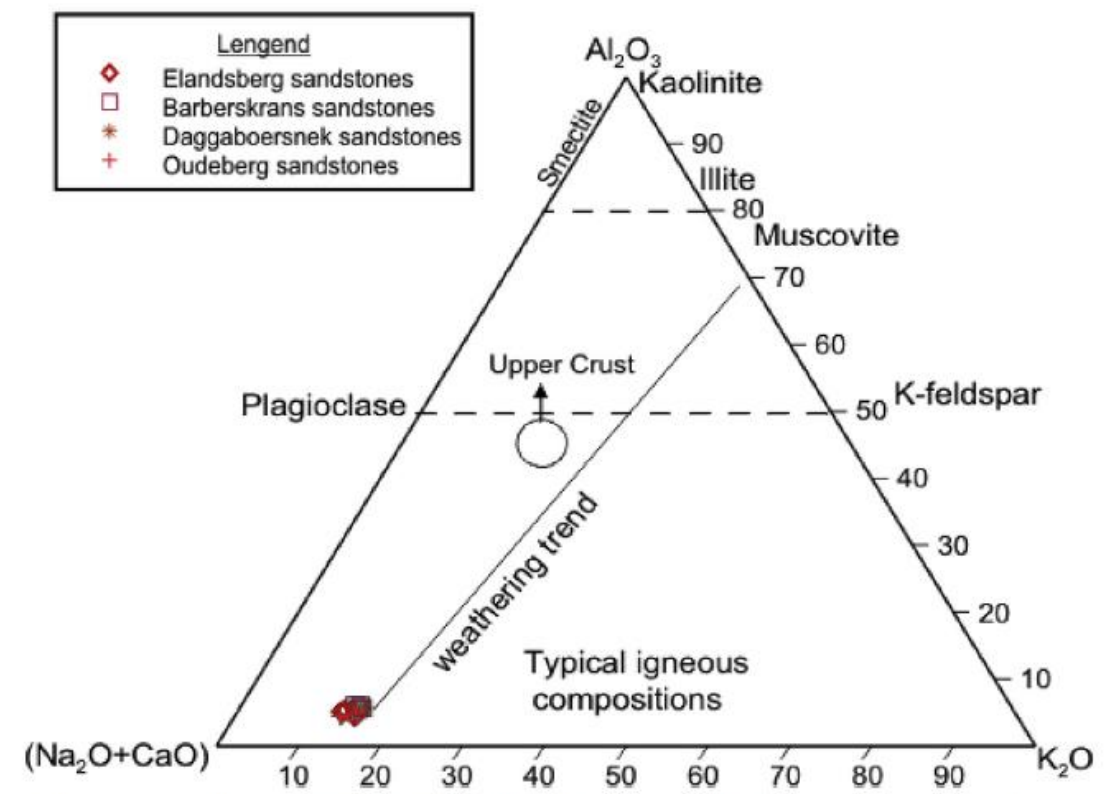

Fig. 7. A-CN-K triangle plot of the extent depiction (after Cingolani et al., 2003), showing the weathering trend and that the Balfour sandstone source was of igneous composition.

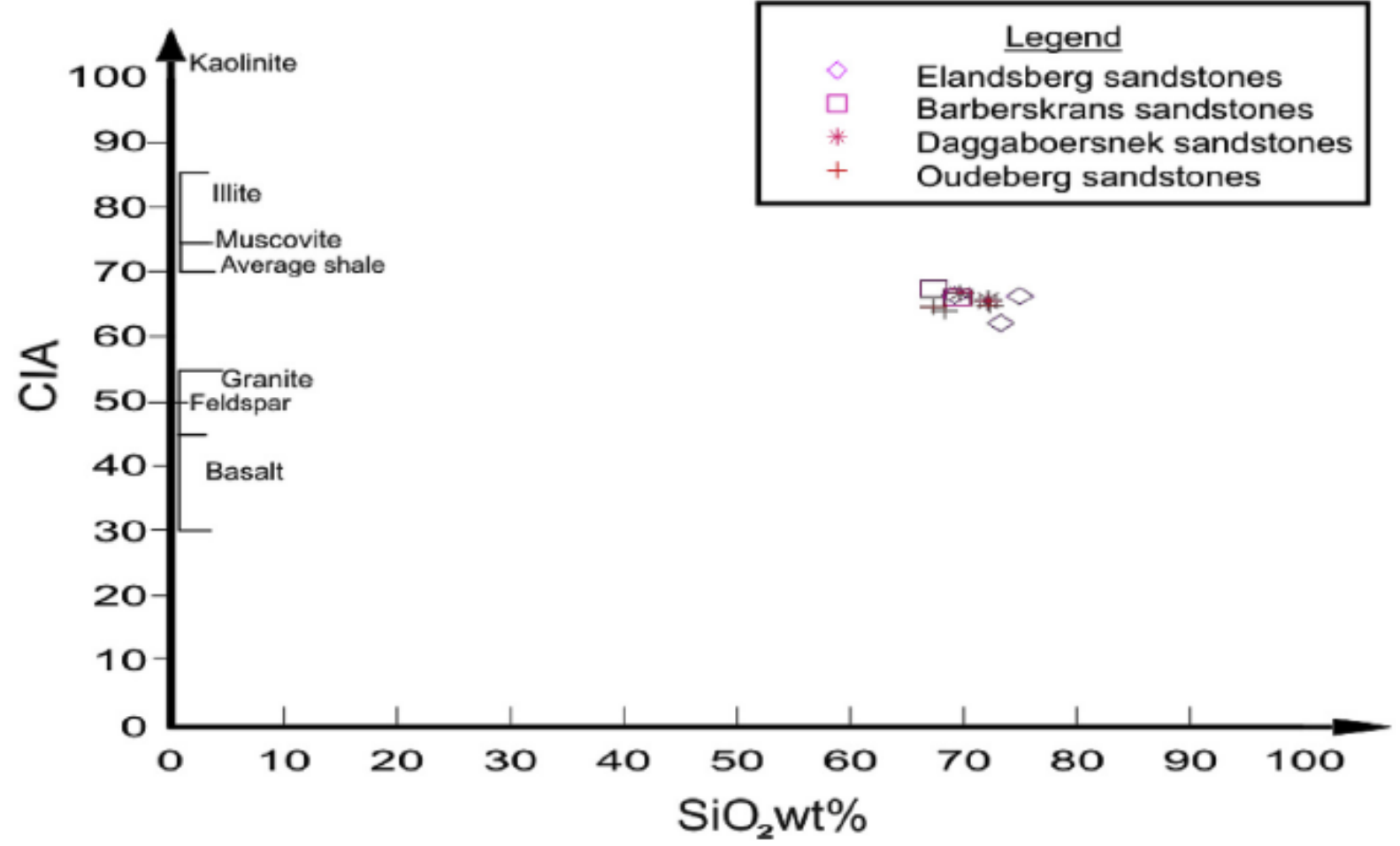

Fig. 8. Plot of $\mathrm{SiO}_{2}$ versus CIA for Balfour and Katberg Formation sandstones (after Nesbitt and Young, 1982). 
The content of $\mathrm{Cr}$ in the studied sediments ranges from 36 to $58 \mathrm{ppm}$ with an overall average of $46.0 \mathrm{ppm}$. Given the $\mathrm{Cr} / \mathrm{Ni}$ ratio which ranges from 2.87 to 5.94 (Table 3 ) is an indication of depletion of metal/silicate volatile siderophile elements, we are suggesting an absence of a mafic source. According to Puchelt (1972) strontium and barium mostly reside in plagioclase and K-feldspar, respectively. Thus, the $\mathrm{Sr}$ concentration may have resulted from either the weathering of plagioclase, since plagioclase is more easily weathered than K-feldspar. It may also be a recrystallization of clay and progressive destruction of feldspars, or can be attributed to low-temperature depositional environments. The concentrations value of the transition elements which include $\mathrm{Cr}, \mathrm{Co}, \mathrm{Ni}$ and $\mathrm{V}$ are a strong indication of a granitic source, as shown in the triangular plot of $\mathrm{Al}_{2} \mathrm{O}_{3}-\left(\mathrm{CaO}+\mathrm{Na}_{2} \mathrm{O}\right)-\mathrm{K}_{2} \mathrm{O}$ (Fig. 7). Thorium and scandium are good indicators of the degree of igneous chemical differentiation processes and it is also an indication of terrigenous deposition (McLennan et al., 1983). A sedimentary rock with $\mathrm{Th} / \mathrm{Sc}$ ratio of $>1$ reflects input from evolved crustal igneous rocks (McLennan et al., 1983). The ratio being less than 0.8 gives an indication that the source is either a mafic rock or a mature or recycled source (Cingolani et al., 2003; Taylor and McLennan, 1985). The analyzed samples have relatively moderate $\mathrm{Th} / \mathrm{Sc}$ ratios (average 1.4 ppm) and therefore reflect input from an evolved crustal igneous source. The $\mathrm{Th} / \mathrm{U}$ ratio in most upper crustal rocks is typically between 3.5 and 4.0 (McLennan et al., 1983). Hence, the Th/U ratio of $0.90-1.90$ is an indication of the intensity of the weathering in the source area and/or sediment recycling. Zircon is among the common heavy minerals, derived from granitic, volcanic, and metamorphic recycled sources. Thus, in the Balfour Formation sandstones, enrichment of $\mathrm{Zr}$ is shown by high $\mathrm{Zr} / \mathrm{Sc}$ ratios. The $\mathrm{Zr} / \mathrm{Sc}$ versus $\mathrm{SiO}_{2}$ reworking and/or selective sorting and clear input from upper crustal igneous sources.

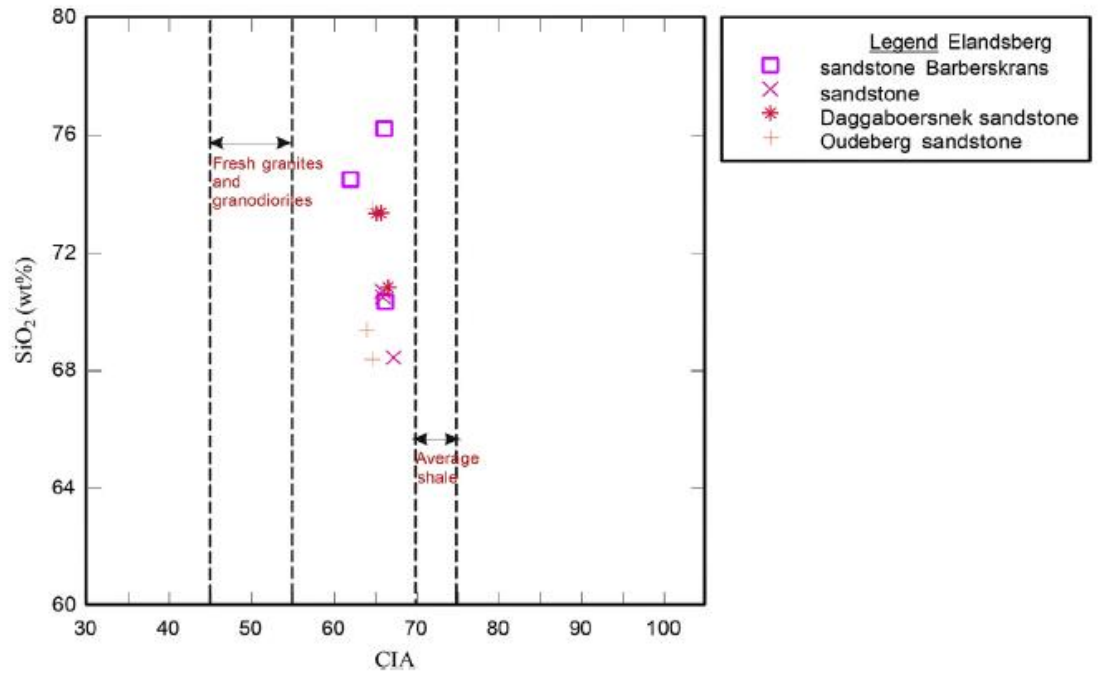

Fig. 9. CIA (Chemical Index of Alteration) versus $\mathrm{SiO}_{2}$ of Balfour sandstones indicates a moderate weathering (after Nesbitt and Young, 1982; Taylor and McLennan, 1985). 


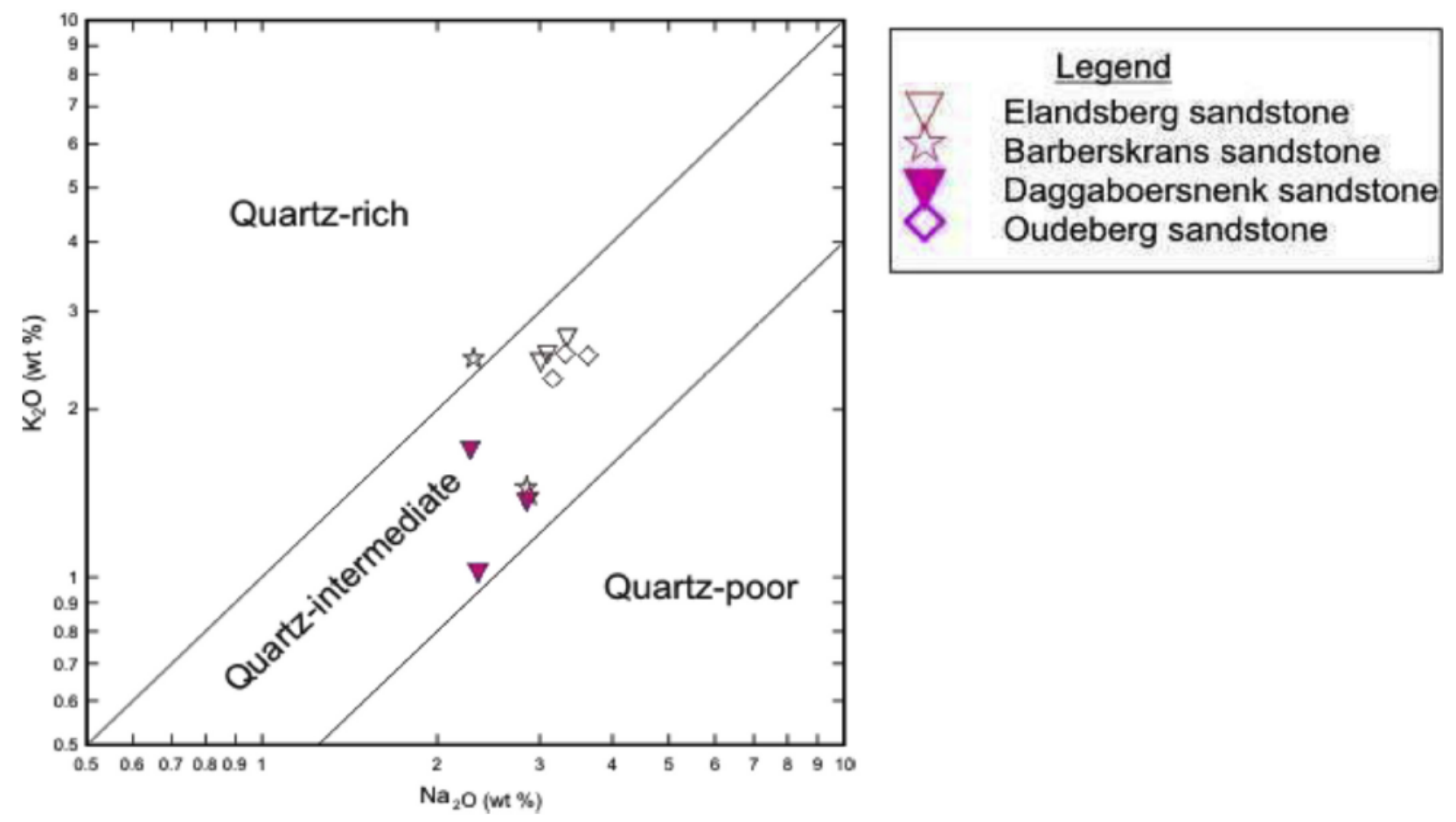

Fig. 10. Quartz content variation amongst sandstone units of the Balfour Formation (after Crook, 1974). The plot shows that the Oudeberg Member has higher quartz content than the Barberskrans and Elandsberg Members while Daggaboersnek Member has low quartz content.

The depletion of $\mathrm{Cs}$ and concentration of $\mathrm{Rb}$ suggest the alteration of mica to K-feldspar given the fractionation of these elements. Elements such as As and $\mathrm{Sb}$ are concentrated in sediment enriched in iron oxides (George and Christian, 2001), thus the depletion of As is an indication that the sediment is low in $\mathrm{Fe}_{2} \mathrm{O}_{3}$ and thus the absence of highly oxidizing conditions. Smectite content also gives an indication that the iron concentration in the clay minerals is relatively low, as shown in the major-element analyses. The low amount of $\mathrm{CaO}$ and $\mathrm{Na}_{2} \mathrm{O}$ indicates low calcite components, while the high concentration of $\mathrm{Ba}$ and low concentration of Th and U suggest that the concentration of these trace elements is linked to clay minerals and mica (Rahmani and Suzuki, 2007; McLennan et al., 1983). This further suggests that the derivation of the sediments could be associated with a weathered granitegneiss terrane or a pre-existing sedimentary terrane. The presence of smectite and diagenetically generated zeolite and the presence of other clay minerals may be a result of both either diagenetic or hydrothermal alteration of feldspar and other aluminum silicate minerals. The presence of zeolite can also be an indication of a volcanic source rock. The CIA, which varies from 63.56 to $67.1 \%$, and points towards sediment recycling processes (Nesbitt et al., 1980) and suggests moderately weathered sources in a relatively warm climate. However, from the A-CN-K plot for the Balfour rocks (sandstone), it is clear that weathering did not proceed to a stage at which the significant components that made up the rock were removed from its sediments. The values of the weathering indices along with the elemental molar ratios suggest moderate to slightly high weathering conditions in the source area and/or during transportation. Tectonic discrimination diagrams (Fig. 4) suggest a source from an active continental margin to continental Island arc for the Balfour sandstones. The substantial increase in the $\mathrm{Zr} / \mathrm{Sc}$ ratio and accompanying decrease 
in the $\mathrm{Th} / \mathrm{Sc}$ ratio indicates that the sediment was derived from a passive margin region (McLennan et al., 1983) as confirmed by Smith (1995). The Th/Sc ratio, ranging from 0.99 to $1.9 \mathrm{ppm}$, with an overall average of $1.40 \mathrm{ppm}$, suggests that the sediments were homogenized by sedimentary recycling. The most used index of sedimentary maturation is the $\mathrm{SiO}_{2} / \mathrm{Al}_{2} \mathrm{O}_{3}$, the average value being 4.97 suggested granitic or rhyolitic sources.

\section{Conclusion}

The geochemical characteristics of the detrital sediments of the sandstone were utilized to infer provenance and weathering conditions in the Eastern Karoo Basin. Geochemical evidence suggests that the compositional maturity of these sandstones is due to recycling and short transportation time. The study also revealed that the sediments are both physically and chemically immature and show signs of reworking. The source area was mainly affected by post-depositional chemical weathering. The most important geochemical result is the concentration of $\mathrm{Ba}, \mathrm{Sr}$ and $\mathrm{Zr}$, which remained immobile despite the moderate degree of weathering. The relative homogeneity of the source area can be seen by the major- and traceelement concentrations and reflects the enrichment of chemically immobile elements ( $\mathrm{Al}, \mathrm{Zr}$ and $\mathrm{Sr}$ ) and the depletion of mobile elements ( $\mathrm{Ca}, \mathrm{Fe}, \mathrm{Na}, \mathrm{K}$ and $\mathrm{Mg}$ ). The origin of the sediments has been shown to be due to moderate weathering and recycling of older rocks, eroded and transported debris, as well as some soluble constituents in this part of the Karoo Basin. The trace element analysis diagrams suggest that the sediments were derived from felsic (granitic) source rocks and were deposited in an active continental margin to Continental Island arc setting. The rocks are dominated by quartzo-feldspathic wackes and provenance data indicates the Cape Fold Belt as the source area. In a regional context of the evolution of the sandstone Formation, the data support the conclusion that the Formation was deposited in a foreland basin generated after the accretion of the Gondwana. It can be concluded that the sediments of the sandstone from Balfour Formation in the Karoo Basin were derived from predominantly igneous, metamorphic, and older sedimentary rocks, therefore suggesting an absence of a mafic source.

\section{Acknowledgements}

Many thanks go to Govan Mbeki Research and Development Fund at the University of Fort Hare for their financial support during the study. Thanks to the Council of Geoscience of South Africa for availing their laboratories to carry out all analyses. Thanks also go to constructive reviewers, all of which led to improvements of the manuscript. 


\section{References}

Akarish, A.I.M., El-Gogary, A.M., 2008. Petrography and geochemistry of lower Paleozoic sandstones, East Sinai, Egypt: implications for provenance and tectonic setting. J. Afr. Earth Sci. 52, 43-54.

Andersson, P.O.D., Worden, R.H., 2006. Stratigraphic variations in mudstone mineral assemblages from a submarine fan-complex: Karoo basin, South Africa. Clay Miner. $41,839-852$.

Armstrong-Altrin, J.S., Lee, Y.I., Verma, S.P., Ramasamy, S., 2004. Geochemistry of sandstones from the Upper Miocene Kudankulam Formation, southern India: implication for provenance, weathering and tectonic setting. J. Sediment. Res. 74 (2), 285-297.

Asiedu, D.K., Suzuki, S., Nogami, K., Shibata, T., 2000. Geochemistry of lower cretaceous sediments, inner zone of southwest Japan: constraints on provenance and tectonic environment. Geochem. J. 34, 155-173.

Bamford, M.K., 2004. Diversity of the woody vegetation of Gondwana, southern Africa. Gondwana Res. 7, 153-164.

Banerjee, A., Banerjee, D.M., 2010. Modal analysis and geochemistry of two sandstones of the Bhander Group (Late Neoproterozoic) in parts of the Central India, Vindhyan basin and their bearing on the provenance and tectonics. Journal of Earth System Science 119, 825-839.

Bhatia, M.R., 1983. Plate tectonics and geochemical composition of sandstones. J. Geol. 91, 611-627.

Bhatia, M.R., Crook, K.A.W., 1986. Trace element characteristic of graywackes and tectonic setting discrimination of sedimentary basins. Contrib. Mineral. Petrol. 92, 181-193.

Catuneanu, O., Hancox, P.J., Rubidge, B.S., 1998. Reciprocal flexural behavior and contrasting stratigraphies: a new basin development model for the Karoo retroarc foreland system, South Africa. Basin Res. 10, 417-439.

Catuneanu, O., Bowker, D., 2001. Sequence stratigraphy of the koonap and middleton fluvial formations in the Karoo foredeep, South Africa. J. Afr. Earth Sci. 33, 579-595.

Catuneanu, O., Elango, H.N., 2001. Tectonic control on fluvial styles: the Balfour Formation of the Karoo basin, South Africa. Sediment. Geol. 140, 291-313.

Catuneanu, O., Hancox, P.J., Cairncross, B., Rubidge, B.S., 2002. Foredeep submarine fans and forebulge deltas: orogenic off-loading in the underfilled Karoo Basin. J. Afr. Earth Sci. 35, 489-502.

Catuneanu, O., 2004. Basement control on flexural profiles and the distribution of foreland facies: the Dwyka Group of the Karoo Basin, South Africa. J. Geol. 32 (6), 517-520.

Catuneanu, O., Wopfner, H., Eriksson, P.G., Cairncross, B., Rubidge, B.S., Smith, R.M.H., Hancox, P.J., 2005. The Karoo basins of south-central Africa. J. Afr. Earth Sci. 43, 211-253.

Cingolani, C.A., Manassero, M., Abre, P., 2003. Composition, provenance and tectonic setting of Ordovician siliciclastic rocks in the San Rafael block: southern extension of the Precordillera crustal fragment, Argentina. J. S. Am. Earth Sci. 16, 91-106. 
Crook, K.A.W., 1974. Lithogenesis and geotectonics: the significance of compositional variation in flysch arenites (graywackes). Society of Economic Paleontology and Mineralogist 19, 304-310.

De Kock, M.O., Kirschvink, J.L., 2003. Paleomagnetic constraints on the Permian-Triassic boundary in terrestrial strata of the Karoo Supergroup, South Africa: implications for causes of the End-Permian extinction events. Gondwana Res. 7, 175-183.

Fedo, C.M., Nesbitt, H.W., Young, G.M., 1995. Unraveling the effects of potassium metasomatism in sedimentary rocks and paleosols, with implications for paleo weathering conditions and provenance. Geology 23, 921-924.

George, W.A.N., Christian, K., 2001. Mineralogical and chemical composition and distribution of rare earth elements in clay-rich sediments from central Uganda. Geochem. J. 35, 13-28.

Hayashi, K.I., Fujisawa, H., Holland, H.D., Ohmoto, H., 1997. Geochemistry of 1.9 Ga sedimentary rocks from northeastern Labrador, Canada. Geochimica et. Cosmochimica. Acta 61, 4115-4137.

Haycock, C.A., Mason, T.R., Watkeys, M.K., 1997. Early Triassic palaeoenvironments in the eastern Karoo foreland basin, South Africa. J. Afr. Earth Sci. 24, 79-94.

Herron, M.M., 1988. Geochemical classification of terrigenous sands and shales from core or log data. J. Sediment. Petrol. 58, 820-829.

Hiller, N., Stavrakis, N., 1984. Permo-Triassic fluvial systems in the southeastern Karoo Basin, South Africa. Palaeogeogr. Palaeoclimatol. Palaeoecol. 34, 1-21.

Holland, H.D., 1978. The Chemistry of the Atmosphere and Oceans. Wiley, New York, pp. $350-351$.

Jafarzadeh, M., Hosseini-Barzi, M., 2008. Petrography and geochemistry of Ahawz sandstone Member of Asmari Formation, Zagros, Iran: implications on provenance and tectonic setting. Mexicana de Ciencias Geologicas 25, 247-260.

Johnson, M.R., 1991. Sandstone petrography, provenance and plate tectonic setting in Gondwana context of the southeastern Cape Karoo Basin. S. Afr. J. Geol. 94, 137-154.

Johnson, M.R., Van Vuuren, C.J., Hegenberger, W.F., Key, R., Shoko, U., 1996. Stratigraphy of the Karoo Supergroup in southern Africa: an overview. J. Afr. Earth Sci. 231, 3-15.

Johnson, M.R., Anhaeusser, C.R., Thomas, R.J., 2006. The Geology of South Africa: Geological Society of South Africa, Council for Geoscience, Pretoria, vol. 691. pp. 461-500.

Keyser, A.W., Smith, R.M.H., 1978. Vertebrate biozonation of the Beaufort Group with special reference to the western Karoo basin. Geological Survey of South Africa 12, $1-36$.

Kitching, J.W., 1977. The Distribution of the Karroo Vertebrate Fauna: Memoir Bernard Price Institute Palaeontological Research, vol. 1. University Witswatersrand, pp. 1131.

Liu, S., Lui, G., Liu, Y., Zhou, Y., Gong, F., Yani, Y., 2007. Geochemistry of middle oligocene-pliocene sandstones from the nanpu sag, bohai bay basin (eastern China): implications for provenance, weathering and tectonic setting. Geochem. J. 41, 359378. 
Lock, B.E., 1978. The Cape Fold Belt of South Africa; tectonic control of sedimentation. Geological Association of London 89, 263-281.

McLennan, S.M., Bock, B., Compston, W., Hemming, S.R., McDaniel, D.K., 2001. Detrital zircon geochronology of Taconian and Acadian foreland sedimentary rocks in new England. J. Sediment. Res. 71, 305-317.

McLennan, S.M., Taylor, S.R., Eriksson, K.A., 1983. Geochemistry of archaean shales from the pilbara Supergroup, western Australia. Genomic et Cosmochimica Acta 47 (7), 1211-1222.

Nesbitt, H.W., Markovics, G., Price, R.C., 1980. Chemical processes affecting alkalis and alkali earth during continental weathering. Geochem. Cosmochim. Acta 44, 666.

Nesbitt, H.W., Young, G., 1982. Early proterozoic climates and plate motions inferred from major element chemistry of lutites. Nature 299, 715-717.

Nagarajan, R., Madhavaraju, J., Nagendra, R., Armstrong-Altrin, J.S., Moutte, J., 2007. Geochemistry of Neoproterozoic shales of the Rabanpalli Formation, Bhima Basin, Northern Karnataka, southern India: implications for provenance and paleo redox conditions. Mexicana de Ciencias Geologicas 24 (2), 150-160.

Nyakairu, G.W.A., Koeberl, C., 2001. Mineralogical and chemical composition and distribution of rare earth elements in clay-rich sediments from central Uganda. Geochem. J. 13-28. 35 .

Oghenekome, M.E., Chatterjee, T.K., Hammond, N.Q., Van Bever Donker, J.M., 2016. Provenance study from petrography of the late permian to early triassic sandstones of the Balfour Formation Karoo Supergroup, South Africa. J. Afr. Earth Sci. 114, 125-132.

Puchelt, H., 1972. Recent iron sediment formation at the Kameni island Santorini (Greece). In: Ore Sediments VIII: International Union of Geological Sciences, vol. 3. pp. 227-245.

Pysklywec, R.N., Mitrovica, J.X., 1999. The role of subduction induced subsidence in the evolution of the Karoo basin. J. Geol. 107, 155-164.

Raymond, A.L., 1995. The study of igneous sedimentary, metamorphic rocks, Wm.C. Brown Communication Inc., United States of America 264-388.

Rahmani, M.J.J., Suzuki, S., 2007. Geochemistry of sandstone from the miocene surama Group, bengal basin, Bangladesh: implications for provenance, tectonic setting and weathering. Geochem. J. 41, 415-428.

Rubidge, B.S., 2005. Re-uniting lost continents-fossil reptiles from the ancient Karoo and their wanderlust: 27th Du Toit Memorial Lecture. Geological Society of South Africa 135-172.

Rubidge, B.S., Hancox, J.P., Catuneanu, O., 2000. Sequence analysis of the EccaBeaufort contact in the southern Karoo of South Africa. S. Afr. J. Geol. 103, 81-96.

SACS (South African Committee for Stratigraphy), 1980. Stratigraphy of South Africa, Part 1: Lithostratigraphy of the Republic of South Africa, South West Africa/Namibia, and the Republics of Bophuthatswana, Transkei and Venda. Handbook 8: Geological Survey of South Africa. pp. 4-20. 
Scheffler, K., Hoernes, S., Schwark, L., 2003. Global changes during CarboniferousePermian glaciation of Gondwana. linking polar and equatorial climate evolution by geochemical proxies. Geology 31 (7), 605-608.

Smith, R.M.H., 1995. Changing fluvial environments across the Permian-Triassic boundary in the Karoo basin, South Africa and possible causes of tetrapod extinctions. Palaeogeography, Palaoeoclimatology, Palaoeoecology 117, 81-104.

Smith, R.M.H., Eriksson, P.G., Botha, W.J., 1993. A review of the stratigraphy and sedimentary environments of the Karoo aged basins of Southern Africa. J. Afr. Earth Sci. 16, 143-169.

Suttner, L.J., Dutta, P.K., 1986. Alluvial sandstone composition and palaeoclimate framework mineralogy. J. Sediment. Petrol. 56, 329-345.

Tankard, A.J., Jackson, M.P.A., Eriksson, K.A., Hobday, D.K., Hunter, D.R., Minter, W.E.L., 1982. Crustal Evolution of Southern Africa, 3.8 Billion Years of Earth History. Springer-Verlag, New York, pp. 5-523.

Taylor, S.R., McLennan, S.H., 1985. The Continental Crust: its Composition and Evolution. Blackwell Scientific Publications, Oxford.

Tordiffe, E.A.W., 1978. Aspects of the Hydrogeochemistry of the Karoo Sequence in the Great Fish River Basin, Eastern Cape Province: Ph.D. Thesis. University of the Orange Free State, Bloemfontein, pp. 307.

Tordiffe, E.A.W., Botha, B.J.V., Loock, J.C., 1985. The relationship between the geology and the groundwater quality of the Great Fish River catchment north of Kommadagga. Water South Africa 11 (2), 99-106.

Visser, J.N.J., Dukas, B.A., 1979. Upward-fining fluviatile megacycles in the Beaufort Group, north of graaff-reinet, Cape Province. Trans. Geol. Soc. S. Afr. 82, 149154.

Winter, H.de la R., 1984. Tectonostratigraphy as applied to the analysis of South african phanerozoic basins: transactions. Geological Society South Africa 87, 169-179.

Wrafter, J.P., Graham, J.R., 1989. Ophiolitic detritus in the ordovician sediments of South mayo Ireland. J. Geol. Soc. 146, 213-215 London.

Yang, J., Du, Y., 2017. Weathering geochemistry and palaeoclimate implication of the early perm mudstones from eastern henan Province, north China. J. Palaeogeogr. 6 (4), 370 